\title{
Comparison of flavors of farm-made 'Kujippong' (Cudrania tricuspidata) fermented vinegar using electronic nose and electronic tongue
}

\author{
Su Jeong Lee, Sun Hee Kim, Hee-Min Gwon, So-Young Kim, Soo-Hwan Yeo* \\ Fermented and Processed Food Science Division, Department of Agrofood Resource, \\ NIAS, RDA, Wanju 55365, Korea
}

\section{전자코와 전자혀를 이용한 농가형 꾸지뽕(Cudrania tricuspidata) 발효식초의 향미 특성 비교 \\ 이수정 · 김순희 · 권희민 · 김소영 · 여수환* \\ 농촌진흥청 국립농업과학원 농식품자원부 발효가공식품과}

\begin{abstract}
The present study intended to compare the flavors of small-scale, farm-made 'Kujippong' (Cudrania tricuspidata) fermented vinegars ( $V \_A 37$ and $V$ B 7 ) produced using two types of acetic acid bacteria (AP A37, AP B7) with those of two commercially available 'Kujippong' vinegars $\left(C V \_A, C V \_B\right)$ using an electronic nose and an electronic tongue. The farm-made vinegars and the commercial vinegars did have different flavors. The first principal component (PC1) of the principal component analysis using the electronic nose confirmed that the pattern of volatility can be used to distinguish between the raw materials used to produce 'Kujippong' vinegar-i.e., stems and fruit. A total of 11 main types of volatile components were identified: ethyl acetate and acetic acid, which indicate fruity and pungent acidic were the main volatile components. Analysis of the four kinds of 'Kujippong' vinegar by the electronic tongue revealed that the farm-made 'Kujippong' fermented vinegar had a richer taste than the commercially available vinegar in terms of soumess and umami. In conclusion, it is possible to differentiate between the flavors of 'Kujippong' fermented vinegars using electronic noses and tongues. These results will contribute to the development of the vinegar industry, thus increasing the income of workers employed in a small-scale farming.
\end{abstract}

Keywords : Cudrania tricuspidata, fermentation, vinegar, electronic nose, electronic tongue

\section{서 론}

꾸지뽕(Cudrania tricuspidata)은 뽕나무과에 속하는 낙엽 성 교목으로 나무껍질과 뿌리는 약재 또는 종이 원료로 사용 되었다. 그 중, 열매는 모양이 둥글고 붉은색을 띠며 동의보 감에서 자양, 강장, 숙취 해소 등의 특성을 가지는 것으로 기 록되어 있으며(Kwon 등, 2014), 항염증, 항당뇨 그리고 항산 화 작용 등과 같은 다양한 생리활성에 관한 연구가 보고되어
있다(Chen 등, 1995; Choi 등, 2011; Ottersen 등, 1997). 그 러나 대부분 생리활성에 관한 연구에 그치며, 꾸지뽕 나무껍 질과 뿌리 외 열매를 이용한 식품 제조법이 미흡하며, 발효 공정을 접목한 연구 보고는 거의 없어 이에 대한 연구 개발이 필요한 실정이다. 우리나라의 대표적 발효식품인 식초는 미 생물의 분해 작용을 통해 풍미 및 저장성 향상 등 다양한 장 점을 가지며(Mok, 2005), 오랫동안 조미료로 사용되었으나, 최근에는 다이어트 등의 건강 기능성 식품으로 사용되고 있

*Corresponding author. E-mail : yeobio@korea.kr, Phone : +82-63-238-3609, Fax : +82-63-238-3843

Received 08 July 2021; Revised 29 September 2021; Accepted 01 October 2021.

Copyright (c) The Korean Society of Food Preservation.

This is an Open Access article distributed under the terms of the Creative Commons Attribution Non-Commercial License (http://creativecommons.org/licenses/by-nc/4.0) which permits unrestricted non-commercial use, distribution, and reproduction in any medium, provided the original work is properly cited. 
다(Ha와 Kim, 2000).

현재, 곡류, 과일 및 약용 등의 다양한 국산 농특산물을 이 용한 식초 제조 시도가 꾸준히 이루어지고 있지만, 농가 또는 소규모 농산업체는 발효 특성이 우수한 종균 사용보다는 전통 적인 자연 발효로 생산 및 판매하는 식초가 대부분을 차지하 고 있다. 이와 같은 전통식초는 발효기간과 숙성기간이 길고, 이로 인하여 이미 - 이취뿐만 아니라, 품질의 균일성 유지와 같 은 어려운 문제점에 노출되어 있다(Baek 등, 2015). 따라서 이 러한 품질을 개선하기 위해 농가형 식초 제조법과 현장 맞춤 형 실용화 기술 확립이 필요하다. 본 연구팀에서는 기능성 작 목으로 알려진 꾸지뽕 열매를 이용한 농가형 식초 제조법을 제시함과 동시에 향미 특성을 규명함으로써 국산 종균으로 제 조한 꾸지뽕 식초의 산업적 이용 가치를 제공하고자 한다.

향미 특성 중 향기 패턴을 나타내는 전자코(electronic nose)는 시료 전체의 향을 동시에 감지하는 특성으로 신속하 게 휘발성분 패턴을 분석하는 기기이며(Dong 등, 2017), 맛 패턴을 분석하는 전자혀(electronic tongue)는 맛 성분과 센서 간의 감응도를 통하여 시료의 맛을 패턴화시키는 기기이다 (Hodgins와 Simmonds, 1995; Vincent, 1999; Wilkens와 Lin, 1970). 현재, 객관적 지표로서 간편한 작동 및 저비용 효과와 함께 빠른 분석 등 다양한 이점을 가진 전자코와 전자혀를 이용한 식초의 향미 특성 연구는 최근 일부 이루어지고 있다 (Chung 등, 2017; Jo 등, 2016). 따라서 본 연구에서는 이러 한 첨단 분석기기를 활용하여 소규모 농산업체에서 2 단 발효
를 통한 꾸지뽕 식초와 전통적 방법으로 제조한 시판 꾸지뽕 식초의 향미 특성의 차이를 규명하고자 한다.

\section{재료 및 방법}

\section{농가형 꾸지뽕 식초 제조}

꾸지뽕 식초 제조는 충남 논산의 소규모 식초제조업체에서 현장 적용시험을 진행하였다. 원료인 꾸지뽕(C. tricuspidata) 열매는 2019년 7월 경남 밀양의 농가에서 수확한 것을 냉동 상태로 보관하며, 유수에 세척 후 파쇄하여 사용하였고, 알코 올 발효를 위해 가수 $(180 \%)$ 및 보당 $\left(24{ }^{\circ} \mathrm{Brix}\right)$ 후 아황산염 (100 ppm)을 첨가하여 잡균의 증식을 억제하였다. 꾸지뽕 발 효주 제조에 적합한 효모(송천효모, $0.3 \%(\mathrm{v} / \mathrm{v}))$ 를 접종 후 알 코올 발효 $\left(25^{\circ} \mathrm{C}, 9\right.$ 일, Alc. $\left.12 \%\right)$ 를 하였고, 이를 조여과 및 제성(Alc. $8 \%$ )한 후, 초산발효를 위한 꾸지뽕 발효주로 사용 하였다.

이들 발효주를 이용하여 꾸지뽕 식초를 제조하기 위해, 본 연구팀에서 분리 - 선발한 2종류의 초산균(A. pasteurianus $\mathrm{A} 37, \mathrm{~B} 7)$ 으로 각각의 종초를 제조하였고, 꾸지뽕 발효주를 $\mathrm{pH}$ 4로 조절한 후, 이들 종초(A. pasteurianus $\mathrm{A} 37, \mathrm{~B} 7)$ 를 각각 $10 \%$ 접종하여 초산발효 $\left(30^{\circ} \mathrm{C}, 30\right.$ 일)를 하였다. 이때 사 용한 발효조는 항아리를 사용하여 정치발효 $\left(30^{\circ} \mathrm{C}, 30\right.$ 일 $)$ 하면 서 초산균 종류(V_A37, V_B7)에 따른 농가형 꾸지뽕 식초 를 제조하였다(Fig. 1).

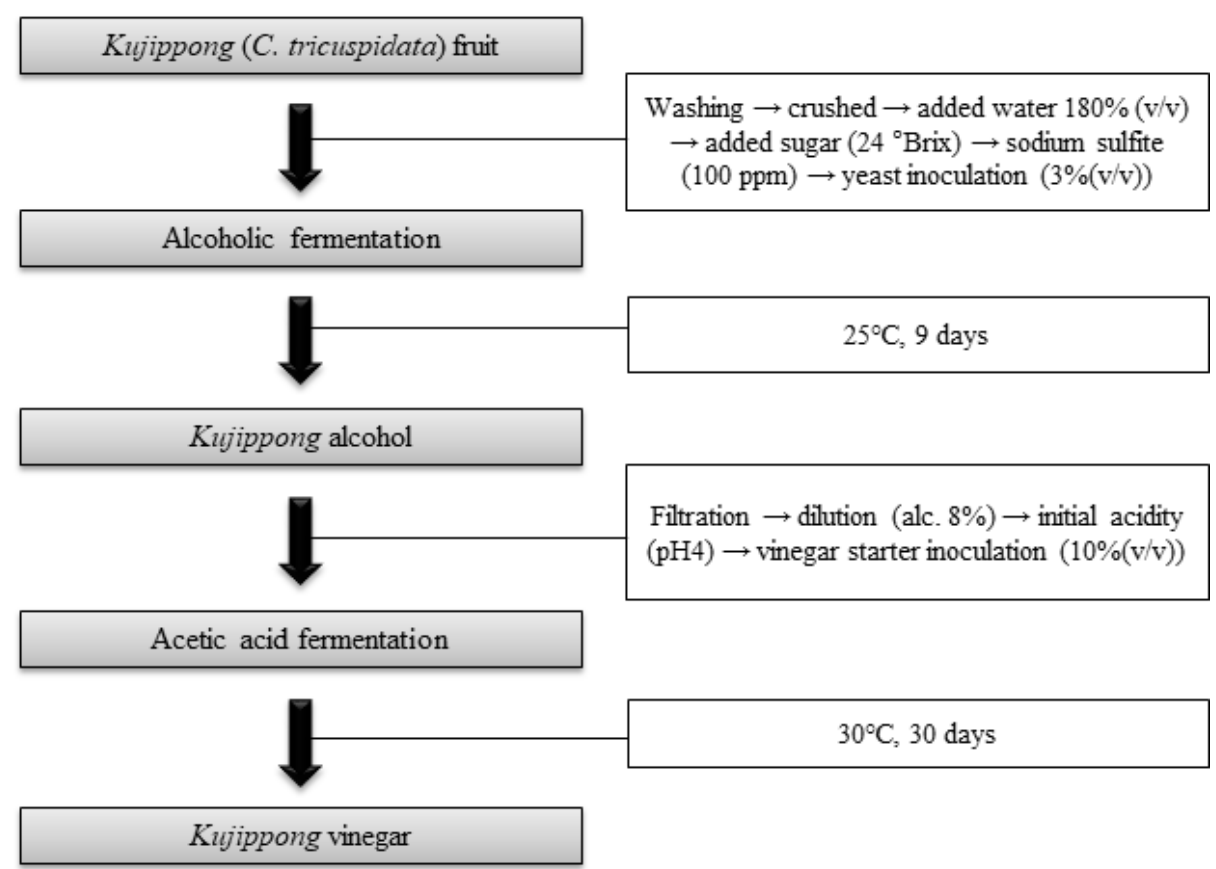

Fig. 1. Manufacturing process of farm-made 'Kujippong' fermented vinegar. 


\section{향미 분석을 위한 시판 꾸지뽕 식초}

본 연구팀에서 제조한 2종류의 농가형 꾸지뽕 식초(V_A37, V_B7)의 향미 특성을 비교 분석하기 위해 국내에서 생산된 2종류의 시판 꾸지뽕 식초(CV_A, CV_B)를 구입하여 사용 하였다. 산도 측정은 phenolphthalein 용액을 지시약으로 0.1 $\mathrm{N} \mathrm{NaOH}$ 표준용액으로 중화적정하고, 초산으로 환산하여 나 타내었다(Table 1).

\section{전자코를 이용한 향기패턴 분석}

현장 적용한 농가형 꾸지뽕 식초와 시판 꾸지뽕 식초를 각 각 $0.1 \mathrm{~mL}$ 를 바이알(vial)에 넣은 후 전자코(Heracles II, Alpha MOS, Toulouse, France)를 이용하여 향기패턴을 분석 하였다. 전자코 시스템은 주입량 $1,000 \mu \mathrm{L}$ 를 유속 $1 \mathrm{~mL} / \mathrm{min}$ 으로 주입하였고, 꾸지뽕 식초의 향기패턴을 분석하기 위해 MTX-5와 MTX-1701의 두 개 칼럼을 병렬로 장착한 후, 2 flame ionization detectors(FID)로 분석하였다. 칼럼으로 통 과하는 시료는 초기온도 $40^{\circ} \mathrm{C}$ 에서 $80^{\circ} \mathrm{C}$ 까지 초당 $1^{\circ} \mathrm{C}$ 씩 증가 하며, $80^{\circ} \mathrm{C}$ 부터는 초당 $3^{\circ} \mathrm{C}$ 씩 증가하는 승온법으로 $250^{\circ} \mathrm{C}$ 에 도달할 때까지 분석하였다. 총 4 회 반복하여 시료 간 성분의 상대적인 함량 차이를 분석하였으며, 각 시료의 향기성분 패 턴 분석은 Alpha MOS사에서 제공된 프로그램 AlphaSoft 14.2 ver.(Alpha MOS, Toulouse, France)을 이용하여 주성분 분석(principal component analysis, PCA)을 하였다.

\section{전자혀를 이용한 맛 성분 패턴 분석}

제조한 농가형 꾸지뽕 식초와 시판 꾸지뽕 식초를 각각 증 류수로 100 배 희석 후, 희석액 $100 \mathrm{~mL}$ 를 전자혀(Astree2, Alpha MOS, Toulouse, France)를 이용하여 시료마다 120초 동안 측정하며 5 회 반복하였다. 전자혀는 7 가지 센서(AHS, 신맛; $\mathrm{CTS}$, 짠맛; $\mathrm{NMS}$, 감칠맛; $\mathrm{PKS}$, 단맛; $\mathrm{ANS}$, 쓴맛; $\mathrm{CPS} ; \mathrm{SCS}$ )를 가지며, CPS와 SCS는 standard로 사용하였다. 7 가지 센서는 각각의 화학성분을 측정한 것이 아니고, 분석 식초의 전체적인 맛을 감지하여 각각의 센서 감응도를 0-10 의 범위를 갖는 맛 스코어로 변환하여 나타내었다. 각 시료의 맛 성분 패턴 분석은 Alpha MOS사에서 제공된 프로그램
AlphaSoft 17 ver.(Alpha MOS, Toulouse, France)을 사용하 여 판별함수 분석(discriminant function analysis, DFA)을 하 였다.

\section{통계분석}

전자코를 이용한 향기패턴 분석은 Alpha Soft 14.2 ver. (Alpha MOS, Toulouse, France)를 사용하였으며, 전자혀를 이용한 맛 패턴 분석은 Alpha MOS사에서 제공된 프로그램 Alpha soft 17 ver.(Alpha MOS, Toulouse, France)을 사용하 여 통계적 유의성을 검토하였다.

\section{결과 및 고찰}

\section{시판 꾸지뽕 식초의 특성 조사}

농가형 꾸지뽕 식초 2종(V_A37, V B7)의 향미 특성을 비교 · 분석하기 위해 국내에서 시판 중인 2 종류의 꾸지뽕 식초를 수집하였고, 이들을 각각 CV_A와 CV_B로 명명하 였다. 꾸지뽕 열매로 제조한 농가형 꾸지뽕 식초 2종 및 시 판 꾸지뽕 식초 CV_A와 달리 CV_B 꾸지뽕 식초는 꾸지뽕 열매와 나무를 혼합하여 제조한 것으로 확인되었다(Table 1). 4종류 꾸지뽕 식초의 산도를 분석한 결과, 우수한 초산균으 로 제조한 농가형 꾸지뽕 식초인 V_A37은 7.2, V_B7은 6.9 로, 시판 중인 CV_A 4.6과 CV_B 6.7보다 산도가 높은 것으 로 보아 사용 원료의 부위, 종균 사용뿐만 아니라, 제조공정 에 따른 차이가 있는 것으로 보인다.

\section{농가형 꾸지뽕 발효식초와 시판 꾸지뽕 식초의 향기패턴 비교}

농가형 꾸지뽕 식초(V_A37, V_B7)와 시판 꾸지뽕 식초 $\left(\mathrm{CV} \_\mathrm{A}, \mathrm{CV} B \mathrm{~B}\right)$ 의 향기패턴 비교를 위해 전자코로 주성분 분 석(PCA) 결과를 Fig. 2에 나타내었다. 제1 주성분 97.152\%, 제2 주성분 $2.402 \%$ 로 나타나 총 $99.654 \%$ 의 누적 점유율을 나타내어 $\mathrm{PC} 1$ 을 기준으로 구분되었다. 즉, 시판용 CV_B 식 초를 제외한 3종류의 꾸지뽕 식초는 음의 방향에 위치하였으 며, 그 중 농가형 꾸지뽕 식초인 V A37과 V B7은 근접하게 위치하는 것으로 보아 시료의 휘발성분이 유사한 것으로 보

Table 1. Description and acidity of farm-made and commercial 'Kujippong' vinegars

\begin{tabular}{cccc}
\hline Vinegars ${ }^{1)}$ & Acidity (\%) & Components & Origin \\
\hline V_A37 & 7.2 & 'Kujippong' fruit & Farm-made \\
V_B7 & 6.9 & 'Kujippong' fruit & Farm-made \\
CV_A & 4.6 & 'Kujippong' fruit & Article on the market \\
CV_B & 6.7 & 'Kujippong' fruit \& stem & Article on the market \\
\hline
\end{tabular}

${ }^{1)}$ V_A37, V_B7, Farm-made 'Kujippong' fermented vinegars; CV_A, CV_B, commercial 'Kujippong' vinegars. 


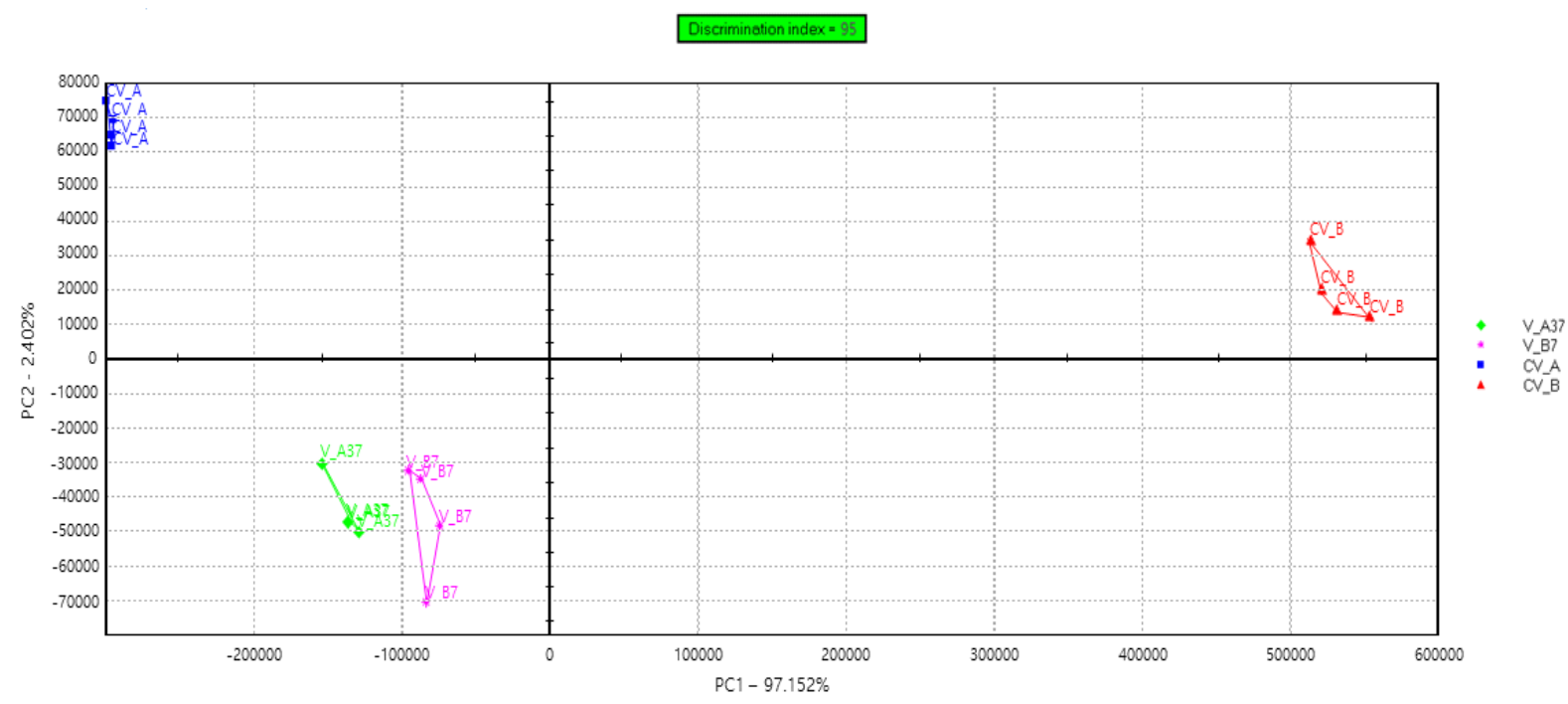

Fig. 2. Principal component analysis in organoleptic characteristics of farm-made and commercial 'Kujippong' vinegars by electronic nose. V_A37 \& V_B7, farm-made 'Kujippong' fermented vinegars produced with each acetic acid bacteria; CV_A \& CV_B, commercial 'Kujippong' vinegars.

인다. 특히, 유일하게 양의 방향에 있는 시판 꾸지뽕 식초인 CV_B는 꾸지뽕 열매로 제조한 3종류 꾸지뽕 식초들(V_A37 과 V_B7, CV_A)과 달리 꾸지뽕 열매와 나무를 넣어 제조한 식초 $(\mathrm{CV}$ B)로 휘발성분의 상대적 차이가 뚜렷하게 나타났 다. 제2 주성분을 분석한 결과에서 전통적 방법으로 제조한 시판 꾸지뽕 식초(CV_A, CV_B)는 양의 방향에 위치하고, 초산균을 사용한 농가형 꾸지뽕 식초(V_A37, V_B7)는 음의 방향에 위치함으로써 향기패턴 차이가 있었다. 이러한 결과 는 Chung 등(2017)과 Yoon 등(2010)의 연구 결과를 바탕으
로 농가형 꾸지뽕 식초와 시판 꾸지뽕 식초의 제조공정뿐만 아니라, 사용 원료에 따라서도 휘발성분 패턴에 차이가 있는 것으로 보인다.

이어 꾸지뽕 식초의 주요 휘발성 성분을 분석한 결과를 Table 2에 나타내었다. 4종류 꾸지뽕 식초의 주된 휘발성 성 분은 총 11종이 동정되었다. 이 중 과일향의 톡 쏘는 산미를 나타내는 ethyl acetate와 acetic acid가 주요 휘발성 성분으로 규명되었다. 특히, 이러한 성분들은 본 연구팀에서 발굴한 산 생성능이 우수한 토착 초산균 사용과 제조공정을 개선한 2종

Table 2. Volatile compounds of farm-made and commercial 'Kujippong' vinegars identified detected by electronic nose

\begin{tabular}{|c|c|c|c|c|c|c|c|}
\hline \multirow{2}{*}{ Column } & \multirow{2}{*}{ RT (s) } & \multicolumn{4}{|c|}{ Peak area } & \multirow{2}{*}{ Compound } & \multirow{2}{*}{ Description } \\
\hline & & V_A37 $7^{1)}$ & V_B7 & CV_A & CV_B & & \\
\hline \multirow{7}{*}{ MTX-5 } & 17.50 & $\begin{array}{l}2,756.2 \\
\pm 110.1^{2)}\end{array}$ & $\begin{array}{l}4,799.5 \\
\pm 222.5\end{array}$ & $\begin{array}{c}672.8 \\
\pm 121.1\end{array}$ & $\begin{array}{l}6,631.4 \\
\pm 867.8\end{array}$ & Acetaldehyde & Fruity, pungent \\
\hline & 19.15 & $\begin{array}{c}139,073.9 \\
\pm 1,437.1\end{array}$ & $\begin{array}{c}175,459.7 \\
\pm 1,747.3\end{array}$ & $\begin{array}{l}34,035.6 \\
\pm 1,250.1\end{array}$ & $\begin{array}{l}371,877.8 \\
\pm 12,960.4\end{array}$ & Ethanol & Alcoholic \\
\hline & 22.49 & $\begin{array}{l}2,763.1 \\
\pm 370.5\end{array}$ & $\begin{array}{l}3,030.2 \\
\pm 337.8\end{array}$ & $\begin{array}{l}7,165.3 \\
\pm 461.3\end{array}$ & $\begin{array}{l}59,374.8 \\
\pm 1,090.4\end{array}$ & 2-Propanol & Alcoholic \\
\hline & 26.38 & $\begin{array}{l}4,696.1 \\
\pm 468.5\end{array}$ & $\begin{array}{l}6,657.5 \\
\pm 492.8\end{array}$ & $\begin{array}{l}5,148.0 \\
\pm 193.5\end{array}$ & $\begin{array}{c}16,145.5 \\
\pm 639.3\end{array}$ & Butane-2,3-dione & Caramelized, fruity \\
\hline & 28.76 & $\begin{array}{l}151,231.7 \\
\pm 11,440.7\end{array}$ & $\begin{array}{l}173,686.5 \\
\pm 12,585.0\end{array}$ & $\begin{array}{l}62,697.5 \\
\pm 3,900.1\end{array}$ & $\begin{array}{c}537,358.5 \\
\pm 4,891.0\end{array}$ & Ethyl acetate & Acidic, fruity \\
\hline & 30.33 & $\begin{array}{l}23,482.8 \\
\pm 2,468.2\end{array}$ & $\begin{array}{l}24,893.1 \\
\pm 2,272.8\end{array}$ & $\begin{array}{c}11,567.3 \\
\pm 394.5\end{array}$ & $\begin{array}{l}26,693.9 \\
\pm 6,387.5\end{array}$ & Acetic acid & Acidic, pungent \\
\hline & 40.27 & $\begin{array}{l}6,768.0 \\
\pm 998.1\end{array}$ & $\begin{array}{l}10,498.7 \\
\pm 1,180.9\end{array}$ & $\begin{array}{l}2,913.8 \\
\pm 235.5\end{array}$ & $\begin{array}{c}14,390.5 \\
\pm 737.7\end{array}$ & 2-Ethyl furan & Acidic, sweet \\
\hline
\end{tabular}


(continued)

\begin{tabular}{|c|c|c|c|c|c|c|c|}
\hline \multirow{2}{*}{ Column } & \multirow{2}{*}{ RT (s) } & \multicolumn{4}{|c|}{ Peak area } & \multirow{2}{*}{ Compound } & \multirow{2}{*}{ Description } \\
\hline & & V_A371) & V_B7 & CV_A & CV_B & & \\
\hline \multirow{2}{*}{ MTX-5 } & 42.54 & $\begin{array}{l}2,585.4 \\
\pm 391.2\end{array}$ & $\begin{array}{l}6,368.5 \\
\pm 301.4\end{array}$ & $\mathrm{ND}^{3)}$ & $\begin{array}{l}9,280.3 \\
\pm 658.9\end{array}$ & Propanoin acid & Acidic, rancid \\
\hline & 44.25 & $\begin{array}{c}14,935.3 \\
\pm 586.3\end{array}$ & $\begin{array}{c}15,812.4 \\
\pm 540.8\end{array}$ & $\begin{array}{l}6,131.2 \\
\pm 218.5\end{array}$ & $\begin{array}{c}13,643.6 \\
\pm 917.4\end{array}$ & 2-Methyl-1-butanol & Balsamic, malty \\
\hline \multirow{7}{*}{ MTX-1701 } & 21.93 & $\begin{array}{l}136,026.8 \\
\pm 1,577.5\end{array}$ & $\begin{array}{c}172,090.4 \\
\pm 1,935.6\end{array}$ & $\begin{array}{l}34,109.8 \\
\pm 1,233.6\end{array}$ & $\begin{array}{l}363,904.2 \\
\pm 12,602.4\end{array}$ & Ethanol & Alcoholic \\
\hline & 24.30 & $\begin{array}{c}3,814.4 \\
\pm 305.2\end{array}$ & $\begin{array}{l}4,711.4 \\
\pm 221.7\end{array}$ & $\begin{array}{l}9,289.6 \\
\pm 258.9\end{array}$ & $\begin{array}{l}64,875.2 \\
\pm 1,025.2\end{array}$ & 2-Propanol & Alcoholic \\
\hline & 31.75 & $\begin{array}{c}72,932.8 \\
\pm 388.4\end{array}$ & $\begin{array}{c}97,156.4 \\
\pm 634.3\end{array}$ & $\begin{array}{c}30,607.1 \\
\pm 975.0\end{array}$ & $\begin{array}{c}503,451.4 \\
\pm 5,504.0\end{array}$ & Ethyl acetate & Acidic, fruity \\
\hline & 38.58 & $\begin{array}{l}9,763.4 \\
\pm 126.0\end{array}$ & $\begin{array}{c}10,805.1 \\
\pm 49.6\end{array}$ & $\begin{array}{l}4,539.7 \\
\pm 106.9\end{array}$ & $\begin{array}{l}6,693.8 \\
\pm 215.6\end{array}$ & Ethyl propanoate & Fruity \\
\hline & 43.31 & $\begin{array}{l}167,894.7 \\
\pm 14,377.8\end{array}$ & $\begin{array}{l}134,678.5 \\
\pm 27,117.3\end{array}$ & $\begin{array}{l}94,531.7 \\
\pm 8,790.8\end{array}$ & $\begin{array}{l}110,509.0 \\
\pm 4,251.6\end{array}$ & Acetic acid & Acidic, pungent \\
\hline & 53.22 & $\begin{array}{c}18,880.3 \\
\pm 36.9\end{array}$ & $\begin{array}{c}19,970.2 \\
\pm 549.0\end{array}$ & $\begin{array}{l}7,922.3 \\
\pm 153.9\end{array}$ & $\begin{array}{l}14,339.2 \\
\pm 1,152.9\end{array}$ & 3-Methyl-1-butanol & Alcoholic, balsamic \\
\hline & 54.53 & $\begin{array}{c}12,798.5 \\
\pm 603.5\end{array}$ & $\begin{array}{l}17,449.3 \\
\pm 2,185.0\end{array}$ & $\begin{array}{c}7,124.7 \\
\pm 1,109.3\end{array}$ & $\begin{array}{l}18,157.2 \\
\pm 2,389.6\end{array}$ & 2-Methyl-1-butanol & Balsamic, malty \\
\hline
\end{tabular}

${ }^{1)}$ Abbreviation of samples referred to Table 1 .

${ }^{2)} \mathrm{Mean} \pm \mathrm{SD}$.

${ }^{3)}$ Not detected.

류 농가형 꾸지뽕 식초가 ethyl acetate에서 peak area 값이 각 V A37은 151,231.7, V B7은 173,686.5로 시판 꾸지뽕 식초 CV_A의 62,697.5보다 높게 나타났다. Acetic acid 또한 농가형 꾸지뽕 식초 V_A37과 V_B7은 23,482.8과 24,893.1로 CV_A 의 $11,567.3$ 보다 2 배 이상 높게 나타났다. Ethanol은 농가형 꾸지뽕 식초에서 알코올 발효 후 초산발효를 진행하면서 알코 올을 모두 소비하지 못하고 남아있는 것으로 보이는데, 이는 초산 발효기간을 늘인다면 잔존 알코올 소비를 통해 산 생성 이 높아질 것으로 여겨진다. 반면에 꾸지뽕 열매와 나무를 혼 합하여 제조한 시판 꾸지뽕 식초 $\mathrm{CV} B$ 는 산미를 나타내는 ethyl acetate와 알코올 향의 ethanol 및 2-propanol 성분이 매 우 높아 시료 간의 차이가 뚜렷하였으며, 상기의 제 1 주성분 분석에서 유일하게 양의 방향에 있는 결과와 유의함을 나타냈 다. 따라서 전자코를 이용한 농가형 꾸지뽕 식초와 시판 꾸지 뽕 식초의 향기패턴 비교·분석을 통해 제조공정과 사용 원료 에 따른 꾸지뽕 식초 간의 성분 차이가 있는 것을 알 수 있다.

\section{농가형 꾸지뽕 발효식초와 시판 꾸지뽕 식초의 맛 성분 비교}

농가형 꾸지뽕 식초(V_A37, V_B7)와 시판 꾸지뽕 식초 $\left(\mathrm{CV} \_\mathrm{A}, \mathrm{CV} \mathrm{B}\right)$ 의 맛 성분 비교를 전자혀로 분석한 결과를 Fig. 3에 나타내었다. 이들 식초의 신맛(-AHS)과 감칠맛
(-NMS)의 강도는 V_A37, V_B7, CV_B, CV_A 순으로, 2종 류의 농가형 꾸지뽕 식초가 시판 꾸지뽕 식초보다 신맛은 1.3-1.5배, 감칠맛은 1.2-1.6배 정도 맛의 강도가 높았다. 단 맛(PKS)의 경우는 시판 꾸지뽕 식초인 CV_B가 가장 높은 강도로 나타났고, 이어서 CV A, V B7, V A37 순으로 단맛 의 차이가 있었다.

짠맛(CTS)과 쓴맛(ANS)은 시판 꾸지뽕 식초인 CV_A가 가장 높게 나타났지만, 시료 간의 차이는 크지 않았다. 사용 원료, 발효법 및 숙성 방법에 따라 식초가 함유하는 유기산과 유리아미노산 구성 함량 차이로 미각적 특성이 있다는 Park (2018) 및 Seo 등(2003)의 보고에 따라 초산균 종류, 발효기 간 및 숙성 조건과의 상관관계 규명 등의 추가적인 연구가 필요하다.

4종류 꾸지뽕 식초의 맛 성분 패턴을 규명하기 위해 전자 혀를 이용한 판별함수 분석(DFA) 결과를 Fig. 4에 나타내었 다. DFA plot 상의 DF1(discriminant function first score)이 $99.762 \%$ 로, $\mathrm{DF} 2$ 는 $0.2302 \%$ 로 나타나 $\mathrm{DF} 1$ 에 의한 4 종류 꾸지뽕 식초 간의 맛 성분 패턴 차이를 판별할 수 있었다. $\mathrm{DF} 1$ 값을 기준으로 2종류의 농가형 꾸지뽕 식초는 모두 음 의 방향에 위치하였고, 시판 꾸지뽕 식초 중 $\mathrm{CV} A$ 는 양의 방향에 CV_B는 중앙에 위치하여 시료 간의 맛 성분 판별이 


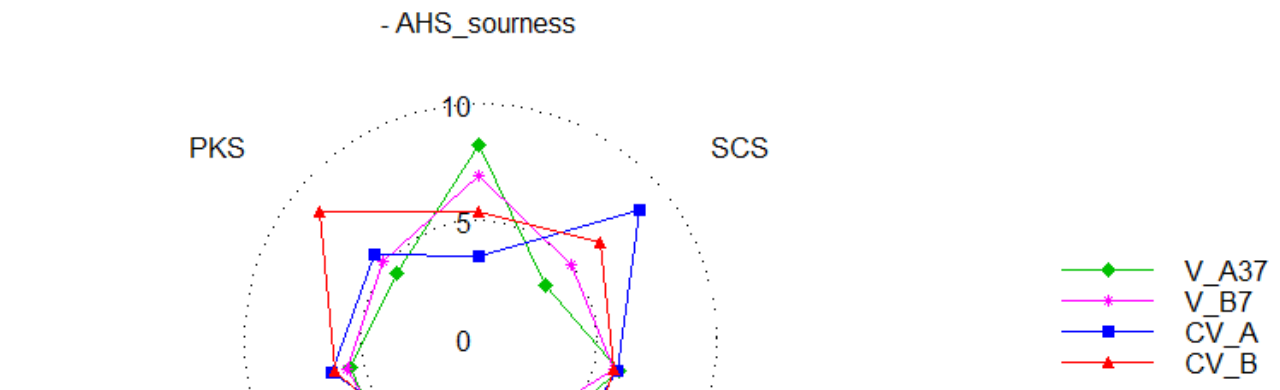

ANS
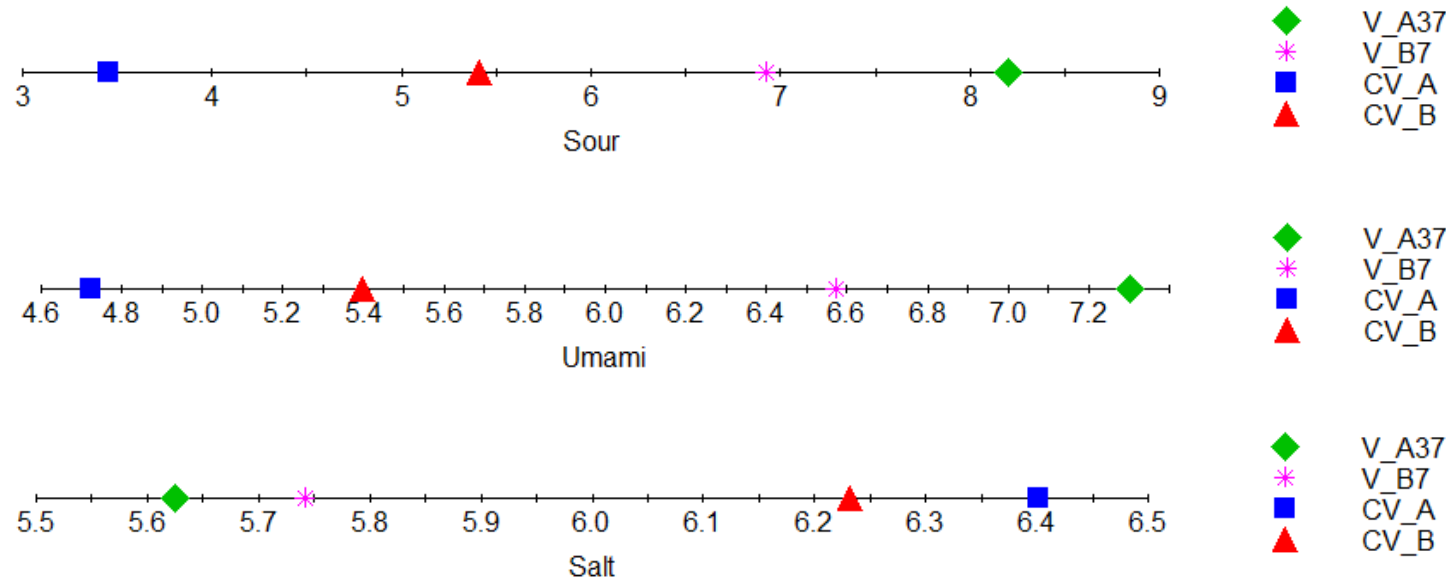

Fig. 3. Intensity scales in organoleptic characteristics of farm-made and commercial 'Kujippong' vinegars by electronic tongue.

V_A37 \& V_B7, farm-made 'Kujippong' fermented vinegars produced with each acetic acid bacteria; CV_A \& CV_B, commercial 'Kujippong' vinegars.

명확하게 구분되었다. 이는 맛 센서 중 Standard(CPS, SCS) 를 제외한 신맛(AHS) 센서가 0.783으로 가장 많은 영향을 받은 것으로 보이며, 소규모 식초 제조장에서 제조한 농가형 꾸지뽕 식초와 시판 꾸지뽕 식초의 맛 성분은 신맛에서 큰 차별성을 나타내었다(Table 3). 이러한 결과는 Song 등 (2016)과 Jo 등(2016)이 보고한 선행연구에서 원료와 제조공 정과 더불어 미생물 작용과 효소활성의 차이에 따라 맛 성분 의 변화가 나타난다는 결과와 유사하였다. 따라서 본 연구에 서는 소규모 식초 사업장에서 제조한 2종류 농가형 꾸지뽕 식초를 시판 꾸지뽕 식초와 맛 성분 패턴을 비교한 결과, 농 가형 꾸지뽕 식초는 특유의 강한 신맛뿐만 아니라, 감칠맛이 많아 시판 꾸지뽕 식초보다 풍부한 맛 성분을 가지는 것으로 나타났다.

\section{요 약}

본 연구는 소규모 식초 사업장에서 현장적용을 통해 2종류 의 초산균(A37, B7)을 이용하여 빚은 농가형 꾸지뽕 식초 (V_A37, V_B7)와 시판 꾸지뽕 식초(CV_A, CV_B)의 향미 특성을 전자코와 전자혀로 분석하였다. 그 결과, 농가형 꾸지 뽕 식초와 시판 꾸지뽕 식초의 향미 특성의 차이점을 확인할 수 있었다. 전자코를 이용한 주성분 분석의 $\mathrm{PC} 1$ 에 따라 꾸지 뽕 열매와 꾸지뽕 나무를 첨가한 꾸지뽕 식초가 원료에 따라 향기패턴이 구분되는 것으로 보였다. 또한, 주된 휘발성 성분 은 총 11종이 동정되었으며, 이 중 과일향의 톡 쏘는 산미를 나타내는 ethyl acetate와 acetic acid가 주요 휘발성 성분으로 나타났다. 4종류의 꾸지뽕 식초를 전자혀로 분석한 결과, 신 


\section{Validation Score $=80$}

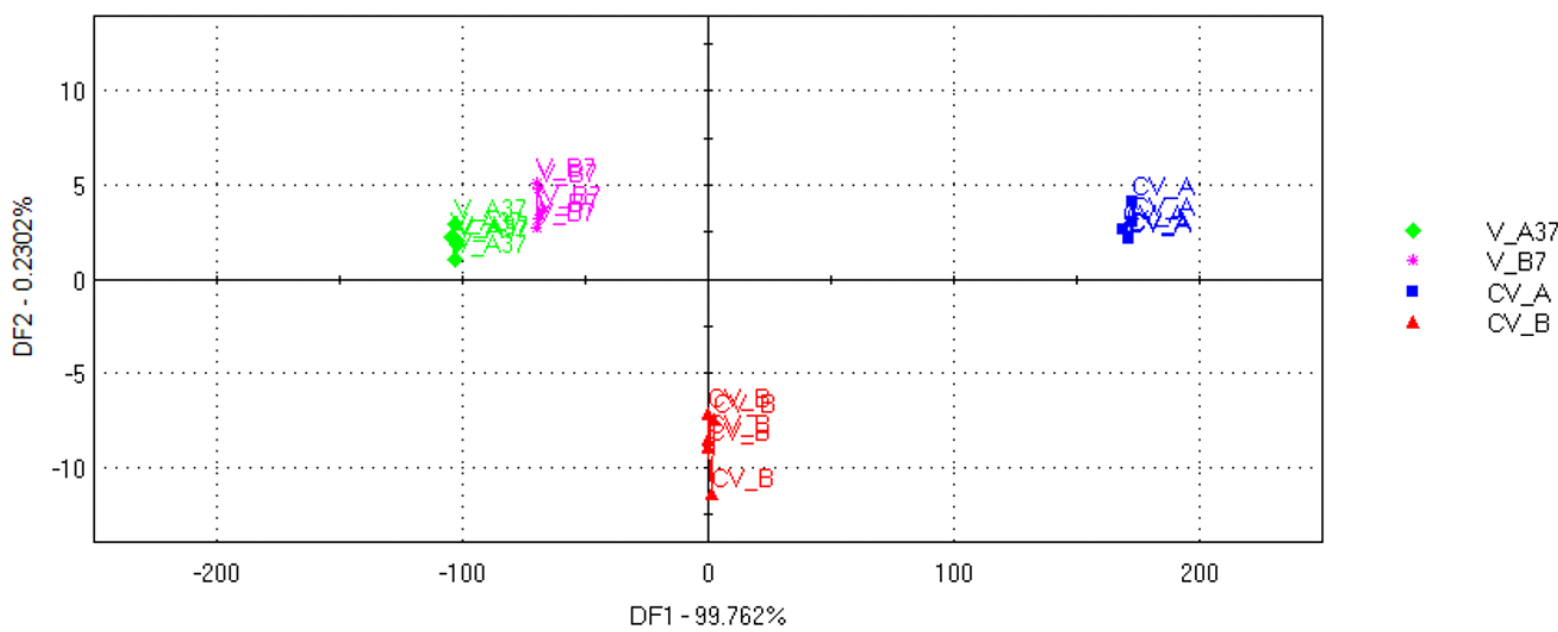

Fig. 4. Discriminant function analysis of the obtained data for farm-made and commercial 'Kujippong' vinegars by electronic tongue. V A37 \& V B7, farm-made 'Kujippong' fermented vinegars produced with each acetic acid bacteria; CV A \& CV B, commercial 'Kujippong' vinegars.

Table 3. Discriminant power values of each sensor

\begin{tabular}{cc}
\hline Sensor $^{1)}$ & Value \\
\hline AHS & 0.783 \\
PKS & 0.621 \\
CTS & 0.026 \\
NMS & 0.251 \\
CPS & 0.626 \\
ANS & 0.002 \\
SCS & 0.885 \\
\hline
\end{tabular}

${ }^{1)}$ AHS, sensor for sourness; PKS, sensor for sweetness; CTS, sensor for saltiness; NMS, sensor for umami (deliciousness); CPS, sensor for standard; ANS, sensor for bitterness; SCS, sensor for standard.

맛과 감칠맛에서 농가형 꾸지뽕 식초 2종 모두 시판용과 비 교해 더욱 풍부한 맛 성분을 가지는 것으로 나타났다. 본 연 구를 통하여 전자코와 전자혀를 이용한 꾸지뽕 식초의 향미 특성을 제시함으로써 소규모 농산업체의 소득향상뿐만 아니 라, 식초산업 발전에 기여할 수 있을 것이다.

\section{감사의 글}

이 논문은 농촌진흥청 농업과학기술개발사업(과제번호: PJ01258801)의 지원에 의해 이루어진 연구 결과의 일부로 이에 감사드립니다.

\section{Conflict of interests}

The authors declare no potential conflict of interest.

\section{ORCID}

Su Jeong Lee https://orcid.org/0000-0002-7519-4685

Soo-Hwan Yeo https://orcid.org/0000-0001-7722-7447

\section{References}

Back CH, Baek SY, Lee SH, Kang JE, Choi HS, Kim JH, Yeo SH. Characterization of Acetobacter sp. strain CV1 isolated from a fermented vinegar. Microbiol Biotechnol Lett, 43, 126-133 (2015)

Chen F, Nakashima N, Kimura I, Kumura M. Hypoglycemic activity and mechanisms of extracts from mulberry leaves (Folium mori) and cortex mori radicis in streptozotocininduced diabetic mice. Yakugaku Zasshi, 115, 476-482 (1995)

Choi SR, Ju IO, Jang I, Ryu J. Antioxidant and antimicrobial activity by harvesting organs in Cudrania tricuspidata. Korean Soc Med Crop Sci, May, 66-67 (2007)

Chung NB, Jo YH, Joe MH, Jeong MH, Jeong YJ, Kwon 
JH. Rice vinegars of different origins: Discriminative characteristics based on solid-phase microextraction and gas chromatography with mass spectrometry, an electronic nose, electronic tongue and sensory evaluation. J Inst Brew, 123, 159-166 (2017)

Dong HM, Moon JY, Lee SH. Discrimination of geographical origins of raw ginseng using the electronic tongue. Korean J Food Sci Technol, 49, 349-354 (2017)

Ha YD, Kim MH. Civilization history of vinegar. Food Indust Nutr, 5, 1-6 (2000)

Hodgins D, Simmonds D. Sensory technology for flavor analysis. Cereal Food World, 40, 186-191 (1995)

Jo YH, Chung NH, Park SW, Noh BS, Jeong YG, Kwon JH. Application of E-tongue, E-nose, and MS-E-nose for discriminating aged vinegars based on taste and aroma profiles. Food Sci Biotechnol, 25, 1313-1318 (2016)

Kwon YS, Park BR, Lee S, Yu HC, Beak SJ, Oh CJ. A study on the morphological characteristics of leaves and fruit of Cudrania tricuspidata in Korea. Korean J Plant Res, 27, 337-343 (2014)

Mok CK. Quality characteristics of instant tea prepared from spray-dried Omija (Schizandra chinensis Baillon) extract grape juice mixture. Food Eng Prog, 9, 226-230 (2005)

Ottersen T, Vance B, Doorenbos NJ, Chang BL, el-Feraly FS. The crystal structure of cudranone, 2,6,3'-trihydroxy4-methoxy-2'-(3-methyl-2-butenyl)-benzophenone: A new antimicrobial agent from Cudrania chochinchinensis. Acta Chem Scand B, 31, 434-436 (1997)

Park YO. Quality comparison of natural fermented vinegars manufactured with different raw materials. J Korean Soc Food Sci Nutr, 47, 46-54 (2018)

Seo JH, Kim YJ, Lee KS. Comparison of physicochemical characteristics of fruit vinegars produced from two-stage fermentation. Food Ind Nutr, 8, 40-44 (2003)

Song NE, Cho HS, Baik SH. Bacteria isolated from Korean black raspberry vinegar with low biogenic amine production in wine. Bras J Microbiol, 47, 452-460 (2016)

Vincent D. Electronic nose: Principal and application. Nature, 402, 351-352 (1999)

Wilkens WF, Lin FM. Gas chromatographic and mass spectral analyses of soybean milk volatiles. J Agr Food Chem, 18, 333-336 (1970) 